\title{
PENGEMBANGAN LKPD PEMBELAJARAN KIMIA BERBASIS PROBLEM SOLVING UNTUK MENUNJANG PEMBELAJARAN KELARUTAN DAN HASILKALI KELARUTAN DI KELAS XI SMA
}

\author{
Meuthia Kartika Putri, Erviyenni*, Sri Haryati, R. Usman Rery, Susilawati \\ Program Studi Pendidikan Kimia Fakultas Keguruan dan Ilmu Pendidikan \\ Universitas Riau \\ E-mail: erviyenni@gmail.com \\ Phone: +6281365628392
}

\begin{abstract}
The objective of this research was to develop the student's activity sheet as support the implementation. This research used a research and development Research and Development (R \& D) with 4-D model of development that includes Definition, Design, Develop and Disseminate. Research and development conducted in the Laboratory of the Department of Study Program of Chemistry Education PMIPA the Faculty of Teacher Training and Education University of Riau. The object of this research was the students' activity paper based on the problem solving. The data analysis techniques used in the study was descriptive statistical analysis, by calculating the percentage of validation value. The average score of the five aspects of student's activity sheet by validator's team, such as the content properness, presentation, didactic, construction (linguistic) and technical (graphical) respectively has a value of eligibility $89.58 \%$, $93.75 \%, 90,96.67 \%$ and $89.5 \%$, totality score validation is $91.9 \%$ meaning the student's activity sheet developed (LKPD Developed) is proper be use in chemistry learning.
\end{abstract}

Key Words: Student Activity Sheet, Problem Solving, Ksp

\begin{abstract}
Abstrak
Penelitian ini bertujuan untuk mengembangkan Lembar Kegiatan Peserta Didik (LKPD) berbasis Problem Solving untuk menunjang pembelajaran kimia di SMA. Jenis penelitian ini adalah penelitian dan pengembangan Research and Development ( $\mathrm{R} \& \mathrm{D})$ dengan model pengembangan 4-D yang meliputi Definition (Pendefinisian), Design (Perancangan), Develop (Pengembangan), dan Disseminate (Penyebaran). Penelitian pengembangan dilakukan di Laboratorium Program Studi Pendidikan Kimia Jurusan PMIPA Fakultas Keguruan dan Ilmu Pendidikan Universitas Riau. Objek penelitian adalah LKPD berbasis Problem Solving. Teknik analisis data yang digunakan dalam penelitian adalah analisis statistik deskriptif, yaitu dengan cara menghitung persentase nilai validasi. Skor rata-rata penilaian kelima aspek kelayakan LKPD oleh tim validator, yaitu kelayakan isi, penyajian, didaktis, konstruksi (kebahasaan) dan teknis (kegrafisan) berturut-turut memiliki nilai kelayakan $89.58 \%$, 93.75\%, 90\%, 96.67\% dan $89.5 \%$ dengan rata - rata keseluruhan $91.9 \%$. Artinya LKPD yang dikembangkan (LKPD Developed) layak digunakan pada pembelajaran kimia.
\end{abstract}

Kata Kunci: Lembar Kegiatan Peserta Didik, Problem Solving, Ksp 


\section{PENDAHULUAN}

Pembelajaran diartikan sebagai proses komunikasi dua arah, pembelajaran dilakukan oleh pihak guru sebagai pendidik, sedangkan belajar dilakukan oleh peserta didik (Sagala, 2010). Peserta didik dalam pembelajaran diposisikan sebagai subjek belajar yang memegang peranan utama, sehingga dikondisikan untuk beraktivitas secara penuh, sedangkan guru diharapkan dapat merancang proses pembelajaran yang memberikan fasilitas atau kemudahan bagi peserta didik sehingga proses pembelajaran berlangsung secara efektif (Sardiman, 2011). Salah satu pembelajaran yang terdapat di sekolah khususnya SMA adalah pembelajaran kimia.

Kimia merupakan salah satu ilmu yang mempunyai peranan penting dalam kehidupan, hampir semua bahan keperluan kita baik langsung atau tidak langsung berkaitan dengan kimia. Materi pelajaran kimia yang diajarkan di SMA/sederajat banyak bersifat pemahaman konsep dan hitungan sehingga diperlukan keaktifan peserta didik dalam proses pembelajaran untuk dapat menguasai kompetensi minimal yang telah ditetapkan.

Kriteria Ketuntasan Minimal (KKM) yang telah ditentukan sekolah masih belum terpenuhi oleh peserta didik hal ini dapat disebabkan karena aktivitas belajar yang belum sesuai dengan yang dikehendaki. Pelaksanaan kegiatan belajar berhubungan erat dengan proses pembelajaran yang dirancang guru, kegiatan pembelajaran yang dikelola guru sampai sekarang masih belum berpusat kepada peserta didik sebagaimana yang dikehendaki kurikulum.

Kegiatan pembelajaran kimia yang berpusat kepada peserta didik dapat terwujud sebagaimana mestinya jika perangkat pembelajaran sudah dirancang secara baik sesuai dengan tuntutan kurikulum. Perangkat yang perlu dipersiapkan guru untuk memenuhi tuntutan kurikulum dalam mewujudkan pelaksanaan proses pembelajaran dengan pendekatan saintifik antara lain adalah Rencana Pelaksanaan Pembelajaran (RPP), Lembar Kegiatan Peserta Didik (LKPD), evaluasi, materi ajar/modul, dan media pembelajaran yang diharapkan dapat mengaktifkan peserta didik.

Lembar Kegiatan Peserta Didik (LKPD) merupakan salah satu bentuk bahan berupa sumber belajar yang digunakan dalam pembelajaran berfungsi sebagai panduan belajar peserta didik dalam menerapkan langkah - langkah pendekatan saintifik dengan maksud memudahkan peserta didik dan guru dalam melakukan kegiatan belajar 
mengajar yang berpusat kepada peserta didik. Penggunaan LKPD dalam pembelajaran bertujuan memberikan kesempatan penuh kepada peserta didik untuk mengungkapkan kemampuan dan keterampilan dalam mengembangkan proses berpikirnya melalui mencari, menebak, bahkan menalar setelah proses mengamati dilalui.

LKPD mata pelajaran kimia yang ada dipasaran secara umum masih berupa pertanyaan soal-soal yang pada dasarnya dikerjakan peserta didik di luar kelas yang sering diberikan sebagai Pekerjaan Rumah (PR) oleh guru. LKPD yang dijumpai di pasaran lebih bersifat informatif, cenderung berisi ringkasan materi, permasalahan dan pertanyaan-pertanyaan yang harus dikerjakan peserta didik tanpa memberikan tuntunan dan bimbingan agar dapat menyelesaikan permasalahan, sehingga peserta didik masih belum memperlihatkan aktivitas yang beragam.

Temuan penulis pada kegiatan Pendidikan Latihan Profesi Guru (PLPG) pada tahun 2015 juga terlihat guru kesulitan dan sangat terbebani terutama dalam merancang perangkat yang mendukung pelaksanaan kurikulum. Keterbatasan guru dalam perancangan perangkat pembelajaran pada hakekatnya sangat berpengaruh pada kualitas pembelajaran secara umum. Khususnya pembelajaran kimia tanpa ketersediaan perangkat LKPD guru akan kesulitan untuk menggiring peserta didik dalam beraktivitas selama proses jika menginginkan pembelajaran yang didominasi peserta didik.

LKPD berbasis problem solving yang dimaksud adalah LKPD yang mencakup komponen-komponen pembelajaran berbasis pemecahan masalah dan menerapkannya dalam serangkaian kegiatan pembelajaran dalam proses di kelas. Peserta didik mencari sendiri pemecahan terhadap masalah yang diberikan serta diberi kesempatan berperan aktif dalam merumuskan masalah, mengemukakan hipotesis, menguji hipotesis, dan mengambil kesimpulan sebagai jawaban pemecahan masalah (Hamdani, 2011).

Belajar merupakan suatu proses aktif dari peserta didik dalam membangun pengetahuan, bukan pasif yang hanya menerima penjelasan guru tentang pengetahuan (Hartono, 2011). Menumbuhkan kerja sama diantara peserta didik secara aktif melalui kegiatan pembelajaran yang mendukung kurikulum dengan pendekatan saintifik, untuk itu dipandang perlu perancangan perangkat pembelajaran dalam hal ini salah satunya adalah LKPD yang berbasis problem solving. Pada rancangan kegiatan ini peneliti mencoba menyusun perangkat pembelajaran berupa LKPD dalam pembelajaran kimia berbasis problem solving dimana secara teoritis LKPD yang dikembangkan sangat 
mendukung keterlaksanaan pembelajaran dengan aktivitas peserta didik yang bervariasi Inovasi kurikulum yang senantiasa terjadi menimbulkan permasalahan baru yang harus dihadapi guru di sekolah, dengan harapan untuk membantu memecahkan permasalahan proses pembelajaran kimia di kelas XI/1 maka dipandang perlu penelitian pengembangan dengan merancang LKPD untuk materi yang bersifat hafalan dan banyak perhitungannya.

\section{METODE PENELITIAN}

Penelitian meliputi validasi Lembar Kegiatan Peserta Didik (LKPD) berbasis problem solving yang dikembangkan dengan menggunakan model pengembangan 4-D. Model pengembangan 4-D memiliki empat tahapan yaitu Define (Pendefinisian), Design (Perancangan), Develop (Pengembangan), dan Disseminate (Penyebaran) (Trianto, 2012). Penelitian ini baru dilakukan sampai tahap pengembangan dikarenakan keterbatasan waktu dan dana.

Objek penelitian yang dimaksud adalah perangkat pembelajaran, yaitu Lembar Kegiatan Peserta Didik (LKPD) berbasis Problem Solving pada materi pokok Ksp. Instrumen penelitian yang digunakan dalam penilaian adalah lembar validasi LKPD, yang berfungsi sebagai instrumen penelitian yang bertujuan untuk mengetahui kriteria kevalidan LKPD yang sedang dikembangkan. Lembar validasi LKPD diberikan kepada tiga orang validator, yaitu 2 orang dosen Pendidikan Kimia Universitas Riau dan satu orang guru kimia SMA/sederajat di Pekanbaru. Untuk penyempurnaan pengembangan LKPD berbasis Problem Solving validator yang dipilih merupakan validator yang berlatarbelakang pendidikan keguruan dan memiliki spesifikasi bidang ilmu kimia.

Teknik pengumpulan data pada penelitian, yaitu berupa hasil validasi LKPD oleh tim validator. Data penelitian LKPD dikumpulkan melalui pengisian lembar validasi oleh validator. Data yang dihasilkan menjadi data yang diolah sehingga didapatkan hasil analisis data. Teknik analisis data yang digunakan adalah analisis statistik deskriptif, yaitu dengan cara menghitung persentase nilai validasi.

$$
\text { Persentase }=\frac{\text { Skor yang diperoleh }}{\text { Skor maksimum }} \times 100 \%
$$




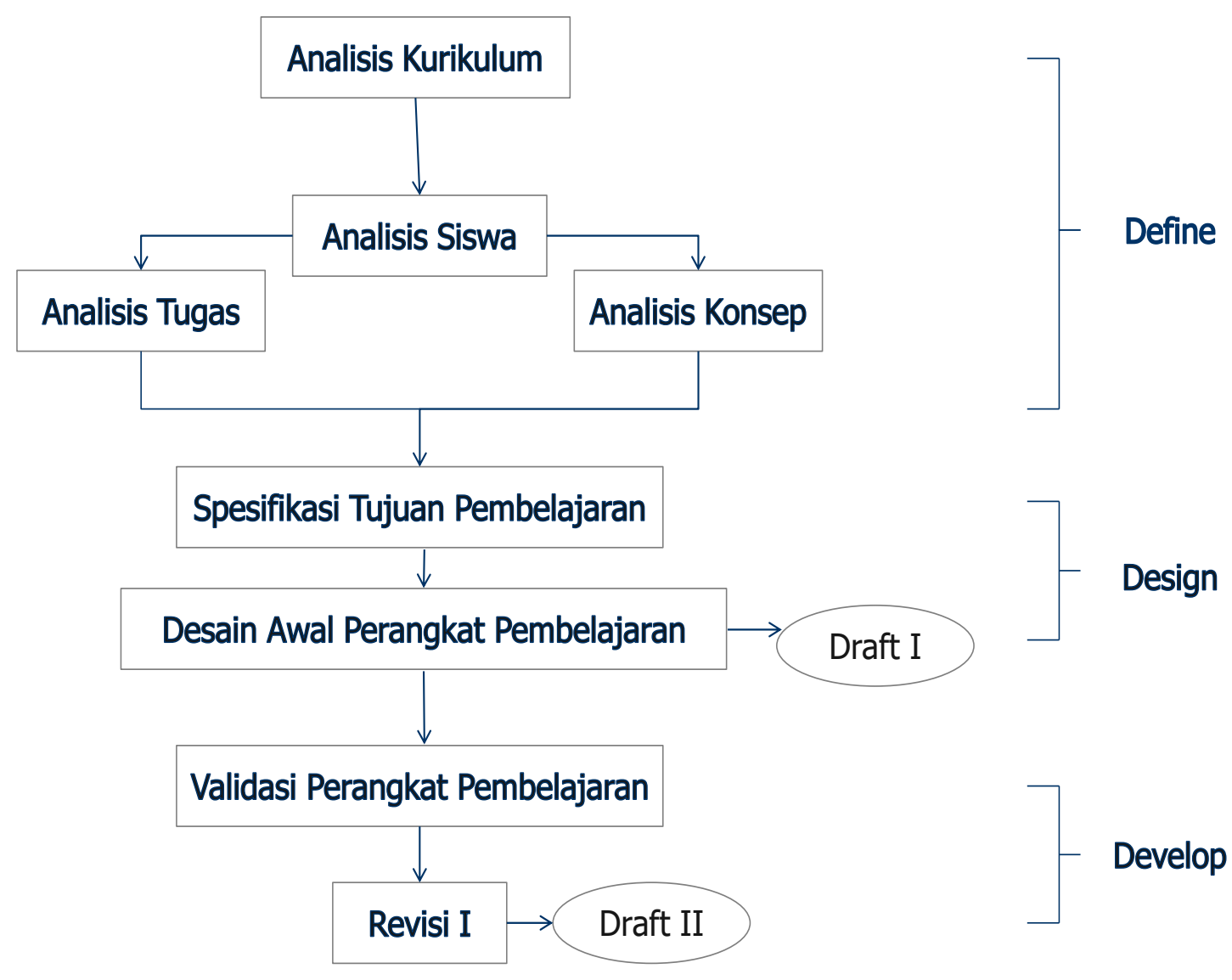

Gambar 1. Alur pengembangan Lembar Kegiatan Peserta Didik (LKPD)

Tingkat kelayakan produk hasil penelitian pengembangan diidentikkan dengan persentase skor. Semakin besar persentase skor hasil analisis data, maka semakin baik tingkat kelayakan produk hasil penelitian pengembangan LKPD. Kriteria tingkat kelayakan analisis persentase produk hasil pengembangan perangkat pembelajaran disajikan dalam Tabel 1 berikut.

Tabel 1. Kriteria Kelayakan Analisis Persentase

\begin{tabular}{|c|c|}
\hline Persentase (\%) & Keterangan \\
\hline $80,00-100$ & Baik/Valid/Layak \\
\hline $60,00-79,99$ & Cukup Baik/Cukup Valid/Cukup Layak \\
\hline $50,00-59,99$ & Kurang Baik/Kurang Valid/Kurang Layak \\
\hline $0-49,99$ & Tidak Baik (Diganti) \\
\hline
\end{tabular}




\section{HASIL DAN PEMBAHASAN}

Pengembangan perangkat LKPD dimulai dengan mentelaah materi pokok kelarutan dan tetapan hasil kali kelarutan dalam hal ini telah dihasilkan perangkat pembelajaran berupa LKPD berbasis problem solving yang diharapkan dapat membantu penyelesaian permasalahan guru dalam melakukan kegiatan proses pembelajaran kimia di sekolah sebagaimana mestinya.

\section{HASIL}

Pada bahagian ini akan diuraikan hasil validasi dari validator yang telah diperoleh dari kegiatan penelitian yang dilakukan. Hasil penelitian berupa perangkat LKPD yang telah dikembangkan untuk materi pokok kelarutan dan tetapan hasil kali kelarutan (Ksp). Hasil validasi digunakan untuk melihat kevalidan perangkat LKPD materi pokok yang dirancang sesuai saran dan perbaikan dari validator seperti; penilaian dari segi kelayakan isi rata-rata nilai dari validator adalah 89.58, penilaian untuk kelayakan penyajian 93.75 , kesesuaian dengan syarat didaktis 86,66 , penilaian syarat konstruksi (kebahasaan) rata-rata 96.67, sedangkan untuk komponen syarat teknis (kegrafisan) memperoleh nilai rata-rata tahapan problem solving 89.5. Skor rata-rata penilaian kelima aspek kelayakan LKPD materi pokok Ksp oleh tiga orang validator secara jelas dapat dilihat pada Tabel 2.

Tabel 2. Skor Rata-rata Penilaian Kelayakan LKPD

\begin{tabular}{|c|c|c|c|c|c|c|}
\hline No & $\begin{array}{c}\text { Aspek yang } \\
\text { dinilai }\end{array}$ & $\begin{array}{c}\text { Skor } \\
\text { Validator } \\
1 \\
(\%)\end{array}$ & $\begin{array}{c}\text { Skor } \\
\text { Validator } \\
2 \\
(\%)\end{array}$ & $\begin{array}{c}\text { Skor } \\
\text { Validator } \\
3 \\
(\%)\end{array}$ & $\begin{array}{l}\text { Skor Rata- } \\
\text { rata } \\
\text { Validasi } \\
(\%)\end{array}$ & $\begin{array}{c}\text { Keteranga } \\
n\end{array}$ \\
\hline 1 & Kelayakan isi & 87.5 & 87.5 & 93.75 & 89.58 & Valid \\
\hline 2 & $\begin{array}{l}\text { Kelayakan } \\
\text { Penyajian }\end{array}$ & 93.75 & 87.5 & 100 & 93.75 & Valid \\
\hline 3 & $\begin{array}{l}\text { Kelayakan } \\
\text { Didaktis }\end{array}$ & 85 & 85 & 90 & 86.66 & Valid \\
\hline 4 & $\begin{array}{l}\text { Kelayakan } \\
\text { Konstruksi } \\
\text { (Kebahasaan) }\end{array}$ & 90.5 & 90.5 & 100 & 96.67 & Valid \\
\hline 5 & $\begin{array}{l}\text { Kelayakan } \\
\text { Teknis } \\
\text { (Kegrafisan) }\end{array}$ & 93.75 & 87.5 & 87.5 & 89.5 & Valid \\
\hline & \multicolumn{4}{|c|}{ Skor rata-rata keseluruhan validasi } & $91.9 \%$ & Valid \\
\hline
\end{tabular}


Berdasarkan skor rata-rata penilaian kelima aspek kelayakan LKPD pada Tabel 2, maka dapat dibuat diagram batang skor rata-rata penilaian dari tiga validator mengenai aspek kelayakan LKPD yaitu kelayakan isi, penyajian, didaktis, konstruksi (kebahasaan) dan teknis (kegrafisan) seperti Gambar 2.

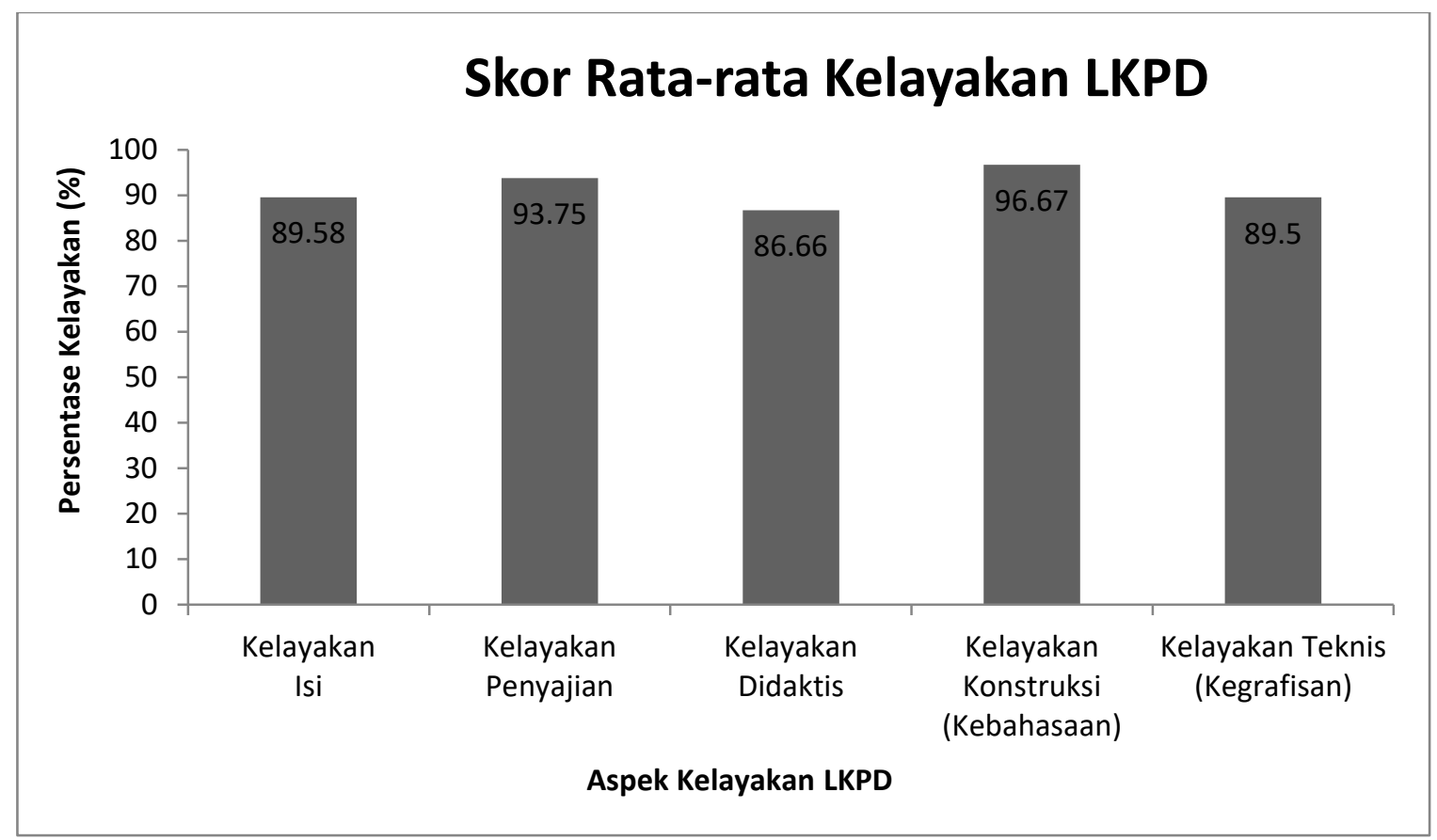

Gambar 2. Hasil analisis LKPD yang dikembangkan sesuai aspek kelayakan isi, penyajian, didaktis, konstruksi (kebahasaan) dan kegrafisan.

\section{PEMBAHASAN}

Validasi yang dilakukan berdasarkan BSNP yan harus memenuhi aspek kelayakan isi, penyajian, didaktis, konstruksi (kebahasaan), dan teknis (kegrafisan). Perangkat LKPD yang dikembangkan menurut validator yang akan bertindak sebagai pengguna di sekolah (Guru) maupun dosen pendidikan kimia sesuai instrumen instrumen penilaian adalah;

\section{Kelayakan Isi:}

Aspek kelayakan isi dengan 10 komponen penilaian tentang ketepatan konsep kimia yang dicantumkan dalam LKPD, kesesuaian dengan Kompetensi Dasar dan Indikator, sesuai substansi materi pokok dan sejalan dengan tahap problem solving. Indikator penilaian LKPD sesuai dengan kebutuhan pembelajaran peserta didik dalam hal ini memenuhi kebutuhan belajar konsep Ksp. Penilaian LKPD dapat mengarahkan peserta didik untuk membangun konsep, kategori layak walaupun kegiatan dalam LKPD 
belum sepenuhnya dapat mengarahkan peserta didik untuk membangun dan mengembangkan konsep terkait materi pembelajaran melalui langkah-langkah pembelajaran pemecahan masalah. Indikator penilaian bahwa LKPD mampu menambah wawasan pengetahuan, memiliki nilai pada kategori baik. Ilustrasi /wacana masalah yang akan diselesaikan oleh peserta didik dalam LKPD dinilai baik dan tidak membingungkan.

Inditator LKPD memiliki kegiatan yang memungkinkan peserta didik untuk mengkomunikasikan pendapat dan hasil kerja dalam kegiatan pembelajaran pada kategori layak, karena dalam rancangan pada bahagian petunjuk LKPD harus dilakukan secara berkelompok,dalam artian jika peserta didik berada dalam kelompok bertujuan agar mereka akan saling berkomunikasi tentang permasalahan yang ditayangkan pada LKPD, sesuai yang dianjurkan Depdikbud 2013 peserta didik harus mengajukan pertanyaan dan mampu menjawab permasalahan yang muncul saat proses pembelajaran. Rata-rata penilaian validator pada aspek kelayakan isi LKPD adalah $89.58 \%$, dengan kategori valid sesuai dengan kategori yang ditetapkan (Sukmadinata, N. S. 2012), layak/valid pada skor $80-100 \%$.

\section{Kelayakan Penyajian:}

Pada bahagian ini memiliki komponen penilaian yang bertujuan untuk menentukan kualitas penyajian pada LKPD terdiri dari lima belas indicator penilaian yaitu; Komponen LKPD memiliki tujuan kegiatan yang jelas, Tim validator menilai bahwa tujuan pembelajaran dalam LKPD sudah sesuai indicator dan operasional. Komponen kelengkapan format LKPD seperti (Judul, Tujuan, Langkah-langkah dan Pertanyaan), untuk reaksi pengendapan perlu direvisi dengan penambahan informasi sebagai pendukung yang dapat menambah wawasan pengetahuan peserta didik karena belum memuaskan. Komponen ketersediaan ruang yang cukup untuk memberi keleluasaan bagi peserta didik untuk menulis maupun menggambarkan hal-hal yang ingin disampaikan oleh peserta didik, tim validator menilai bahwa LKPD telah menyediakan ruang kosong yang cukup untuk memberi keleluasaan bagi peserta didik untuk menuliskan jawaban pertanyaan maupun kesimpulan dari pembelajaran. Perlu juga membatasi ruang atau kolom kosong untuk penulisan jawaban yang diperkirakan sesuai dengan kebutuhan pengerjaan soal bertujuan agar peserta didik menuliskan 
kalimat atau jawaban yang singkat dan jelas. Validator menyarankan desain pada LKPD mesti harus lebih menarik lagi agar peserta didik tidak merasa bosan ketika dalam kegiatan membaca dilakukan revisi desain Skor rata-rata validasi pada aspek penyajian adalah $93.75 \%$, termasuk kategori layak menurut validator.

Sesuai Depdiknas 2008 bahwa struktur LKPD memiliki kelengkapan format yakni memiliki komponen pertanyaan. Tugas/pertanyaan harus menarik perhatian peserta didik supaya tidak menjenuhkan, didiskusikan dengan validator untuk diperbaiki sebagaimana menurut (Ridwan Sani, 2014) bahwa peserta didik dilibatkan dalam menjawab pertanyaan dan latihan guna memantapkan pengetahuannya. Indikator untuk membimbing peserta didik dalam memecahkan masalah disarankan untuk diperbaiki dengan menambahkan informasi pada permasalahan yang dicanangkan. Contoh dan ilustrasi yang mendukung kejelasan pemaparan materi dengan kategori penilaian layak. Komponen membimbing peserta didik melakukan langkah-langkah pemecahan masalah dalam hal ini soal-soal yang diberikan belum mampu membimbing peserta didik untuk melakukan langkah-langkah pemecahan yang diberikan, dilakukan revisi terhadap soalsoal pada tahap act on the strategy sesuai atas saran dan masukan dari validator sehingga dirancang soal yang lebih bervariasi.

\section{Kelayakan Didaktis:}

Menyajikan lima indikator penilaian mencakup menuntun peserta didik dalam menemukan konsep, memperhatikan perbedaan peserta didik, permasalahan yang disajikan mendorong rasa percaya diri peserta didik karena tahapan dalam jawaban soal sudah direncanakan runtut, dimulai dari menjawab tahapan mendasar dalam hal ini peserta didik memberikan jawaban melalui langkah yang teratur untuk menemukan konsep. Skor rata-rata validasi pada aspek didaktis adalah $86.66 \%$ termasuk kategori layak menurut validator.

\section{Kelayakan Konstruksi (Kebahasaan):}

Memuat lima indikator penilaian diantaranya LKPD dapat dibaca dengan baik, menurut tim validator teks dalam LKPD menggunakan kalimat yang jelas, bersifat komunikatif, dengan catatan perlu mengganti kalimat perintah menjadi kalimat berupa ajakan sehingga lebih menyentuh dan akrab dengan peserta didik, contohnya “ 
diskusikan dengan teman-teman anggota kelompokmu guna memahami materi secara lebih mendalam diganti dengan kalimat yang berbunyi 'anda akan lebih mudah memahami permasalahan dalam materi ini jika bekerja sama dan berbagi informasi dalam kelompok. Indikator yang dikemukakan sesuai dengan kaidah Bahasa Indonesia yang baku, menurut Daryanto, 2014 bahwa mengembangkan kemampuan berbahasa yang benar dapat membantu sesorang mengungkapkan pendapat dengan jelas. Menurut validator kalimat-kalimat yang digunakan dalam LKPD telah memenuhi kaidah Bahasa Indonesia yang baku. Indikator kelayakan kebahasaan yang digunakan dengan nilai kelayakan rata-rata $96.67 \%$.

\section{Kelayakan Teknis (Kegrafisan):}

Tersusun dari lima indikator komponen-komponen penilaian yang bertujuan untuk menilai ketepatan tata letak (layout), tulisan, gambar/foto pada LKPD. Komponen LKPD menggunakan jenis dan ukuran huruf yang baik dan sesuai. Teks materi LKPD menggunakan jenis huruf Time New Roman, ukuran huruf (font) 12 dan teks rata kirikanan. Komponen LKPD memiliki tata letak (layout) yang cocok. validator menilai bahwa LKPD memiliki tata letak (layout) halaman yang seimbang, rapi serta tidak mengganggu pemaparan materi. Komponen LKPD memiliki ilustrasi/gambar/foto yang baik, sesuai dan berhubungan dengan konsep. LKPD belum sepenuhnya menggunakan gambar yang berhubungan dengan konsep, kebanyakan gambar dalam LKPD berupa gambar motivasi sehingga perlu revisi. Contoh dari gambar yang telah direvisi antara lain pada LKPD 3 tentang pengaruh penambahan ion senama dimana pada penambahan ion senama terjadi perubahan dari bening menjadi putih namun pada gambar sebelumnya di LKPD kurang jelas diganti. Komponen LKPD memiliki desain tampilan yang menarik. Validator menilai bahwa desain tampilan LKPD cukup menarik. Skor rata-rata validasi pada aspek kegrafisan adalah $89.5 \%$. Berdasarkan kriteria kelayakan perangkat pembelajaran pada Tabel 1 termasuk kategori layak.

\section{KESIMPULAN}

Produk perangkat berupa LKPD materi pokok kelarutan dan tetapan hasil kali kelarutan (Ksp) yang dihasilkan sudah valid/layak menurut validator berdasarkan aspek 
kelayakan isi, penyajian, didaktis, konstruksi (kebahasaan), dan teknis (kegrafisan). LKPD materi pokok Ksp yang telah dihasilkan untuk tiga kali tatap muka di kelas.

\section{SARAN}

Disarankan kepada peneliti lain untuk mencoba merancang LKPD pembelajaran kimia materi pokok yang lain, dalam pengembangan perlu diperhatikan untuk ilustrasi gambar agar memilih gambar-gambar yang ditampilkan untuk mempermudah pemahaman peserta didik.

Pengembangan Lembar Kegiatan Peserta Didik (LKPD) dikatakan berhasil apabila valid dan reliabel. Sedangkan LKPD yang dikembangkan ini baru melalui tahap validitas untuk menguji kevalidan LKPD dan uji coba terbatas berupa respon peserta didik/mahasiswa terhadap LKPD yang dikembangkan. Oleh karena itu diharapkan agar LKPD yang dikembangkan dilanjutkan dengan uji coba produk, revisi produk, dan uji coba lapangan untuk mendapatkan nilai reliabilitasnya agar bisa ditentukan apakah LKPD ini layak digunakan di sekolah secara menyeluruh atau tidak.

\section{DAFTAR PUSTAKA}

Daryanto, 2014. Pembelajaran Tematik, Terpadu, Terintegrasi (Kurikulum 2013). Gava Media. Jogjakarta.

Depdikbud. 2013. Permendikbud No. 66 Tahun 2013 Tentang Standar Penilaian Pendidikan. Permendikbud RI. Jakarta.

Depdiknas. 2008. Panduan Pengembangan Bahan Ajar. Direktorat Jenderal Manajemen Pendidikan Dasar dan Menengah, Departemen Pendidikan Nasional. Jakarta.

Hamdani. 2011. Strategi Belajar Mengajar. Pustaka Setia. Bandung.

Hartono. 2011. PAIKEM Pembelajaran Aktif Inofatif Kreatif Efektif dan Menyenangkan. Zanafa. Pekanbaru.

Ridwan Sani. 2014. Pembelajaran Saintifik untuk Kurikulum 2013. Bumi Aksara. Jakarta.

Sagala. 2010. Konsep dan Makna Pembelajaran. Alfabeta. Bandung.

Sardiman. 2011. Interaksi \& Motivasi Belajar Mengajar. PT Raja Grafindo Persada. Jakarta.

Sukmadinata, N. S. 2012. Pendekatan Penelitian dan Pengembangan Pendidikan. Universitas Pendidikan Indonesia.

Trianto. 2012. Mendesani Model Pembelajaran Inovatif-Progresif. Kencana. Jakarta. 